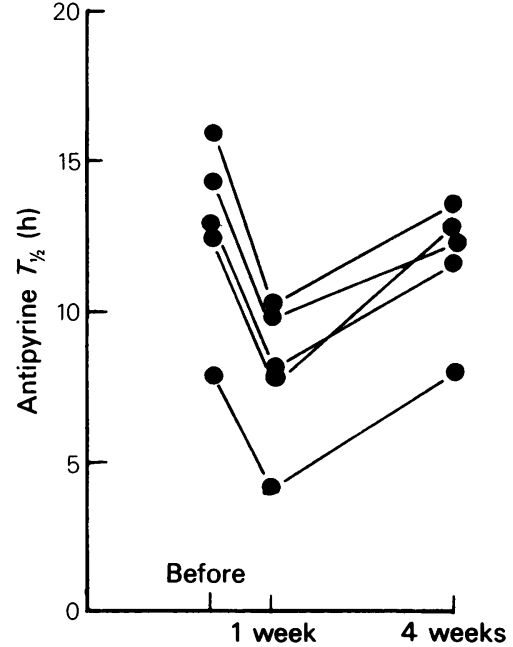

Figure 1 Antipyrine half-life in five patients before and after surgery under general anaesthesia.

term effects of a variety of surgical procedures and many different anaesthetic regimes on antipyrine elimination have yielded variable results. Elfstrom, Johansson \& Lindgren (1976) found antipyrine elimination increased on the fourth or fifth day after operation and only four of the nine patients received halothane during anaesthesia. Pessayre and his colleagues (1978) studied antipyrine clearance 3 days

\section{References}

BROWN, B.R. \& SIPES, I.G. (1977). Biotransformation and hepatotoxicity of halothane. Biochem. Pharmac., 26, 2091-2094.

ELFSTROM, J., JOHANSSON, H. \& LINDGREN, S. (1976). Postoperative disappearance of phenazone from plasma in man. Eur. J. clin. Pharmac., 10, 63-68.

INMAN, W.H.W. \& MUSHIN, W.W. (1978). Jaundice after repeated exposures to halothane: a further analysis of reports to the Committee on Safety of Medicines. Br. med. J., 2, 1455-1456.

PESSAYRE, D.. ALLEMAND, H., BENOIST, C., AFIFI, F. FRANCOIS, M. \& MENHAMON, J.P. (1978). Effect of after surgery. Following short operations $(2$ h) clearance was increased but following longer operations $(4 \mathrm{~h})$ antipyrine clearance was decreased. Only six of their eighteen patients received halothane.

Enzyme induction occurs in rats after $2 \mathrm{~h}$ of halothane anaesthesia (Ross \& Cardell 1978). In the present study, although the number of patients is small, surgery under a standardised general anaesthetic consisting of thiopentone, pancuronium, nitrous oxide and halothane for approximately $1 \mathrm{~h}$ resulted in significant enzyme induction apparent at 1 week returning to preoperative values at 4 weeks. An identical sequence of changes was seen in every patient. This may explain in part why a second halothane anaesthetic within a short period is more likely to produce hepatotoxicity.

\section{W.S. NIMMO}

Department of Anaesthesia, Western Infirmary, Glasgow, G11 6NT

\section{P.G. THOMPSON}

Department of Obstetrics, Royal Infirmary, Edinburgh

\section{L.F. PRESCOTT}

Department of Clinical Pharmacology \& Therapeutics, Royal Infirmary, Edinburgh

Received March 6, 1981 surgery under general anaesthesia on antipyrine clearance. Br. J. clin. Pharmac., 6, 505-513.

PRESCOTT, L.F., KING, I.S., BROWN, L., BALALI, M. \& ADRIAENSSENS, P. (1978). HPLC in clinical pharmacological studies of analgesic drugs. Proc. Anal. Div, Chem. Soc., 16, 300-302.

ROSS. W.T. \& CARDELL. R.R. (1978). Proliferation of smooth endoplasmic reticulum and induction of microsomal drug-metabolizing enzymes after ether or halothane. Anesthesiology, 48, 325-311.

STEVENSON. H. (1977). Factors influencing antipyrine elimination. Br. J. clin. Pharmac., 4, 261-265.

\title{
INTRAOPERATIVE PHARMACOKINETICS OF DEXAMETHASONE
}

The synthetic glucocorticoid dexamethasone is often given in high dosage during neurosurgical operations to prevent, or reduce, cerebral oedema. The pharmacokinetics of the drug have been investigated by several workers, often in healthy subjects and sometimes employing potentially non-specific assays, though one pharmacokinetic study using a specific high pressure liquid chromatography method is now available (Tsuei et al., 1979). It is not yet known whether the various perturbations of the internal environment which may occur during operative neurosurgery under general anaesthesia produce significant alterations in the pharmacokinetics of dexamethasone. We have attempted to investigate 
Table 1 Personal data and values of pharmacokinetic parameters for the subjects studied

\begin{tabular}{|c|c|c|c|c|c|c|c|c|}
\hline Subject & $\begin{array}{c}\text { Age } \\
\text { (years) }\end{array}$ & Sex & $\begin{array}{c}\text { Weight } \\
(k g)\end{array}$ & Disease & $\begin{array}{c}\text { Dexamethasone } \\
\text { phosphate } \\
\text { dose }(\mathrm{mg})\end{array}$ & $\begin{array}{l}T_{1 / 2} \\
(h)\end{array}$ & $\begin{array}{l}\text { Clearance } \\
\left(l k^{-1} h^{1}\right)\end{array}$ & $\begin{array}{c}V_{d} \\
\left(l k^{-1}\right)\end{array}$ \\
\hline 1 & 65 & $\mathbf{M}$ & 82 & Cerebral metastasis & 5 & 3.83 & 0.161 & 0.888 \\
\hline 2 & 70 & $\mathrm{~F}$ & 60 & Acoustic neuroma & 5 & 5.13 & 0.170 & 1.258 \\
\hline 3 & 39 & $\mathbf{M}$ & 73 & Acoustic neuroma & 10 & 5.77 & 0.156 & 0.752 \\
\hline $4 a$ & 31 & $F$ & 53 & Pituitary adenoma & 10 & 3.35 & 0.371 & 1.792 \\
\hline $4 b$ & & & & - & 10 & 0.75 & 0.253 & 0.273 \\
\hline $5 a$ & 57 & $\mathbf{M}$ & 78 & Acoustic neuroma & 5 & 2.27 & 0.169 & 0.553 \\
\hline $5 b$ & & & & - & 5 & 2.50 & 0.192 & 0.691 \\
\hline 6 & 27 & $\mathrm{~F}$ & 63 & Pituitary adenoma & 10 & 1.75 & 0.675 & 1.706 \\
\hline $7 \mathbf{a}$ & 45 & $\mathrm{~F}$ & 53 & Acoustic neuroma & 10 & 3.89 & 0.614 & 3.489 \\
\hline $7 b$ & & & & - & 10 & 0.70 & 0.872 & 0.881 \\
\hline $8 \mathrm{a}$ & 60 & $\mathbf{M}$ & 66 & Meningioma & 5 & 2.04 & 0.387 & 1.138 \\
\hline $8 b$ & & & & - & 5 & 0.80 & 0.692 & 0.798 \\
\hline 9 & 34 & $\mathrm{~F}$ & 75 & Acoustic neuroma & 10 & 0.96 & 0.708 & 0.986 \\
\hline $10 \mathrm{a}$ & 57 & $\mathbf{M}$ & 84 & Acoustic neuroma & 10 & 3.28 & 0.245 & 0.682 \\
\hline $10 \mathrm{~b}$ & & & & - & 10 & 14.90 & 0.091 & 1.945 \\
\hline 11 & 10 & $\mathrm{~F}$ & 32 & Craniopharyngioma & 5 & 0.64 & 0.426 & 0.389 \\
\hline 12 & 9 & $\mathbf{M}$ & 35 & Congenital brain cyst & 5 & 1.55 & 0.942 & 2.108 \\
\hline 13 & 46 & $\mathbf{M}$ & 70 & Cerebral aneurysm clipping & 20 & 1.13 & 0.529 & 0.862 \\
\hline \multirow[t]{2}{*}{14} & 61 & $\mathbf{M}$ & 82 & Acoustic neuroma & 5 & 0.81 & 0.576 & 0.673 \\
\hline & & & & & $\begin{array}{l}\text { Mean } \\
\text { s.d }\end{array}$ & $\begin{array}{r}2.95 \\
\pm 3.28\end{array}$ & $\begin{array}{r}0.433 \\
\pm 0.264\end{array}$ & $\begin{array}{c}1.151 \\
\pm 0.769\end{array}$ \\
\hline \multicolumn{5}{|c|}{ Values of Tsuei et al. (1979) } & $\begin{array}{l}\text { Mean } \\
\text { s.d }\end{array}$ & $\begin{array}{r}2.96 \\
\pm 0.85\end{array}$ & $\begin{array}{r}0.216 \\
\pm 0.032\end{array}$ & $\begin{array}{c}0.765 \\
\pm 0.249\end{array}$ \\
\hline
\end{tabular}

this matter by carrying out serial measurements of plasma dexamethasone levels after administration of the drug during the course of neurosurgery under general anaesthesia. While such potentially complicated circumstances are not conventional ones for carrying out pharmacokinetic work, they are the real situation in which the drug is used successfully in clinical practice. Hence knowledge of dexamethasone pharmacokinetics in these circumstances is clinically relevant.

Intravenous dexamethasone phosphate was given during the course of craniotomy in 14 patients. The personal details of these patients, the dexamethasone phosphate dose given, and the indications for neurosurgery are set out in Table 1. All operations were carried out under general anaesthesia induced by thiopentone and maintained by nitrous oxide and oxygen. All patients received muscle relaxants, mainly alcuronium, and premedication with phenobarbitone and atropine. During operation all patients received intravenous fluid containing glucose and electrolytes, in volumes of from 1.0 to 2.51 . Four patients received whole blood, the maximum volume given being $600 \mathrm{ml}$.

Three patients (Cases 6, 9,13) each received $500 \mathrm{ml}$ intravenous mannitol during surgery, and two (Cases 11 and 13) commenced phenytoin therapy during the operation, whilst two (Cases 4 and 8 ) were already taking this drug preoperatively. All but two subjects
(Cases 3 and 13) had received oral and parenteral dexamethasone preoperatively, usually for several days, and three (Cases 6,9 and 11) were given intraoperative cortisol as well as intraoperative dexamethasone.

Prior to the intraoperative administration of dexamethasone phosphate, and at half-hourly intervals thereafter, venous blood was collected for plasma dexamethasone assay. The drug was given into a leg vein, and the blood samples taken from an arm vein. Sampling continued until the time of the subsequent dexamethasone dose (usually 4 to $6 \mathrm{~h}$ after the first). In four subjects (Cases 5, 7,8 and 10) the time course of plasma dexamethasone levels was also followed as far as possible after a second dose. One subject (Case 4) was studied at two separate craniotomies. Occasionally blood samples taken in the theatre were lost in transit to the laboratory.

Whole plasma dexamethasone levels were measured (as dexamethasone alcohol), using the high pressure liquid chromatographic assay of Cham et al. (1980). This assay can detect a minimum of $10 \mathrm{ng}$ dexamethasone and is linear over the concentration range 0.01 to $1.00 \mathrm{mg} / \mathrm{l}$. From the plasma dexamethasone levels at $30 \mathrm{~min}$, and subsequently, and the occasional additional levels taken at $15 \mathrm{~min}$, it seemed that the decline in plasma drug concentration was a biexponential process. Unfortunately sufficient early data points were not available to determine an $\alpha$ value 
with any confidence. Terminal ( $\beta$ phase) half-lives were determined by least squares linear regression fitting to the semi-logarithmically transformed data. Area under the plasma level curve was determined by trapezoidal rule integration, with area under the curve from the last measured data point to infinity being calculated by dividing the last measured plasma concentration $\left(C_{t}\right)$ by $\beta$ (Gibaldi \& Perrier, 1975). Where indicated, the immediate pre-dose plasma concentration (resulting from previous dexamethasone administration) was also divided by $\beta$ and subtracted from the area under the curve, to compensate for the effect of the previous drug dose. Dose divided by area under the curve yielded the whole plasma clearance of the drug, and clearance values divided by $\beta$ allowed estimation of the apparent volume of distribution $\left(\mathrm{V}_{\mathrm{d}} \beta\right)$.

The values of the pharmacokinetic parameters in individual patients are shown in Table 1. Although there was substantial variation in the individual values, and the terminal half-life value for Case 10-b was so widely deviant that it must be suspect, the mean half-life of $2.95 \mathrm{~h}(2.29 \mathrm{~h}$ if the deviant value is excluded) agreed reasonably well with the mean value of the dexamethasone half-life obtained with a specific HPLC assay by Tsuei et al. (1979) viz. $2.86 \mathrm{~h}$ $(2.37 \mathrm{~h}$ in females and $3.35 \mathrm{~h}$ in males). In the present study the difference in half-life between the sexes either including $(\mathrm{F}=2.15 \mathrm{~h}, \mathrm{M}=3.53 \mathrm{~h})$ or excluding the deviant half-life value $(\mathrm{F}=2.15, \mathrm{M}=2.39 \mathrm{~h})$ were not statistically significant $(t=0.905 ; P>0.30$ and $t=$ $0.324, P>0.70$, respectively). Regression analysis

\section{References}

CHAM, B.E., SADOWSKI, B., O'HAGAN, J.M., DE WYTT, C.N., BOCHNER, F. \& EADIE, M.J. (1980). High performance liquid chromatographic assay of dexamethasone in plasma and tissue. Therapeutic Drug Monitoring, 2, 373-377.

GIBALDI, M. \& PERRIER, D. (1975). Pharmacokinetics. New York: Marcel Dekker Inc. showed no statistically significant effect of age on dexamethasone half-life. Clearance and volume of distribution values obtained in the present study were both higher than those obtained by Tsuei et al. (1979) (Table 1). These differences may reflect consequences of prior exposure to drugs which may induce the hepatic mixed oxidase system, as well as effects of intraoperative administration of drugs and fluids.

It would then appear that in the pharmacokinetically complex situation in which dexamethasone is used during neurosurgery, the disposition parameters of the drug do not differ to any marked degree from those which apply when the drug is given for the first time to healthy volunteers. The significance of the higher dexamethasone clearance values is uncertain.

This work was supported by a grant from the Queensland Cancer Fund.

J. MCCAFFERTY, T.R.O'R. BROPHY, J.D. YELLAND, B.E. CHAM, F. BOCHNER* \& M.J. EADIE

Departments of Medicine and Surgery, University of Queensland, Royal Brisbane Hospital, Brisbane 4029, Australia

${ }^{*}$ Present address: Department of Clinical and Experimental Pharmacology, University of Adelaide, Adelaide, Australia

Received May 14, 1981

TSUEI, S.E., MOORE, R.G., ASHLEY, J.J. \& McBRIDE, W.G (1979). Disposition of synthetic glucocorticoids. I. Pharmacokinetics of dexamethasone in healthy adults. J. Pharmacokin. Biopharm., 7, 249-264.

\section{ERYTHROCYTE AND PLASMA ASPIRIN ESTERASE}

Enzymes able to hydrolyse aspirin are present in blood and have been termed 'aspirin esterases'. Rainsford et al. (1980) have shown that the main plasma aspirin esterase activity is associated with the plasma cholinesterases.

Most publications in this field seem to ignore the contribution of the red cell to aspirin hydrolysis. Admittedly several previous reports (Morgan \& Truitt, 1965; Mulinos \& Ardam, 1950; Harthon \& Hedstrom, 1971) have mentioned in passing that whole blood has a higher enzymatic activity than serum or plasma but the contribution from the cellular fraction has not been extensively studied.

In the present study a u.v. method was used to measure aspirin esterase activity (Rylance \& Wallace, 1980). In this, phosphate buffer $(0.139 \mathrm{M}$; pH 7.0; $9.5 \mathrm{ml})$, aspirin solution $(7.2 \mathrm{~mm}$ in isotonic saline; $5.0 \mathrm{ml})$ and the sample to be tested $(0.5 \mathrm{ml})$ were mixed, incubated at $37^{\circ} \mathrm{C}$ and samples removed at $5 \mathrm{~min}$ and suitable intervals thereafter. The samples were centrifuged for $10 \mathrm{~min}$ and the absorbance of the clear solutions read at $300 \mathrm{~nm}$. The 